University of Nebraska - Lincoln

DigitalCommons@University of Nebraska - Lincoln

USDA National Wildlife Research Center - Staff Publications
U.S. Department of Agriculture: Animal and Plant Health Inspection Service

2010

\title{
The economic impacts to commercial farms from invasive monkeys in Puerto Rico
}

\author{
Richard M. Engeman \\ USDA-APHIS-Wildlife Services, s_r100@yahoo.com \\ Jose' E. Laborde \\ Puerto Rico Department of Agriculture \\ Bernice U. Constantin \\ USDA-APHIS-Wildlife Services
}

Stephanie A. Shwiff

USDA/APHIS/WS National Wildlife Research Center, stephanie.a.shwiff@aphis.usda.gov

Parker Hall

USDA-APHIS-Wildlife Services

See next page for additional authors

Follow this and additional works at: https://digitalcommons.unl.edu/icwdm_usdanwrc

Part of the Environmental Sciences Commons

Engeman, Richard M.; Laborde, Jose' E.; Constantin, Bernice U.; Shwiff, Stephanie A.; Hall, Parker; Duffiney, Anthony; and Luciano, Freddie, "The economic impacts to commercial farms from invasive monkeys in Puerto Rico" (2010). USDA National Wildlife Research Center - Staff Publications. 901.

https://digitalcommons.unl.edu/icwdm_usdanwrc/901

This Article is brought to you for free and open access by the U.S. Department of Agriculture: Animal and Plant Health Inspection Service at DigitalCommons@University of Nebraska - Lincoln. It has been accepted for inclusion in USDA National Wildlife Research Center - Staff Publications by an authorized administrator of DigitalCommons@University of Nebraska - Lincoln. 


\section{Authors}

Richard M. Engeman, Jose' E. Laborde, Bernice U. Constantin, Stephanie A. Shwiff, Parker Hall, Anthony Duffiney, and Freddie Luciano 


\title{
The economic impacts to commercial farms from invasive monkeys in Puerto Rico
}

\author{
Richard M. Engeman ${ }^{a}$, , José E. Laborde ${ }^{b, c}$, Bernice U. Constantin ${ }^{d}$, Stephanie A. Shwiff ${ }^{\text {, }}$ \\ Parker Hall ${ }^{\mathrm{d}}$, Anthony Duffiney ${ }^{\mathrm{d}}$, Freddie Luciano ${ }^{\mathrm{b}, \mathrm{c}}$ \\ ${ }^{a}$ USDA/APHIS/WS National Wildlife Research Center, 4101 LaPorte Avenue, Fort Collins, CO 80521-2154, USA \\ ${ }^{\mathrm{b}}$ Office of the Secretary, Puerto Rico Department of Agriculture, P.O. Box 10163, San Juan, PR 00908, USA \\ ${ }^{\mathrm{C}}$ Empresas Puertorriqueñas de Conservación, P.O. Box 66, Ensenada, PR 00647-0068, USA \\ ${ }^{\mathrm{d}}$ USDA/APHIS/WS, 2820 East University Avenue, Gainesville, FL 32641, USA
}

\section{A R T I C L E I N F O}

\section{Article history:}

Received 4 June 2009

Received in revised form

29 October 2009

Accepted 30 October 2009

\section{Keywords:}

Agricultural losses

Exotic species

Human-wildlife conflict

Invasive species

Patas monkey

Rhesus macaque

Wildlife damage

\begin{abstract}
A B S T R A C T
Beginning in the 1930s and continuing through the 1970s, rhesus macaques and patas monkeys were introduced to presumed secure locations, primarily coastal islets, in Puerto Rico. Escapes into the wild began almost immediately after introduction. Today the combined range of the two species covers approximately $600 \mathrm{~km}^{2}$ of southwestern Puerto Rico, where serious conflicts with agricultural interests have resulted. The Puerto Rico Department of Agriculture surveyed about $90 \%$ of commercial farmers in the range of the monkeys to begin quantifying damage by monkeys and the associated economic losses during the years 2002-2006. During that time, total economic losses by commercial farmers to monkeys increased from $\$ 1.13$ million USD to over $\$ 1.46$ million per year. Of these amounts, the economic losses due to farmers avoiding monkey damage by switching from fruit and vegetable crops to less rewarding land use (primarily hay or pastureland) increased from $\$ 490,000$ to $\$ 1.33$ million per year. The losses reported from the survey represent only a portion of economic losses to the invasive monkeys. Subsistence and other smaller farms and agriculture were not included in the survey. We also discuss many other economic issues surrounding the impacts of the invasive monkeys, but for which sufficient data are not available for economic analyses. These include concerns such as destruction of native (especially endangered) wildlife, threat of disease spread, and property damage, all of which would also have to be considered to fully evaluate invasive monkey economic impacts in Puerto Rico.
\end{abstract}

Published by Elsevier Ltd.

\section{Introduction}

The notion of significant monkey damage to agricultural crops in the U.S. and its territories is novel because monkeys are not native there. An exception to this notion of no agricultural monkey damage in the U.S. now exists in Puerto Rico where two species of invasive, free-ranging monkeys are expanding their ranges in agriculturally productive southwestern Puerto Rico. Both species, rhesus macaques (Macaca mulatta) and patas monkeys (Erythrocebus patas) are well-known as crop raiders in their native ranges in Asia and Africa, respectively (e.g., Sekhar, 1998; Weladji and Tchamba, 2003). Only a few studies have documented amounts and values of crop losses to these species in their native ranges, and we are aware of no such documentation for them as invasive species.

\footnotetext{
* Corresponding author. Tel.: +1970 266 6091; fax: +1970 2666063.

E-mail address: richard.m.engeman@aphis.usda.gov (R.M. Engeman).
}

Monkeys were brought to a number of locations in southwestern Puerto Rico (mostly small islands along the southwest coast) for a variety of purposes. Escapees from these sites produced the wild invasive populations found today through a large area of southwestern Puerto Rico. The introduction of monkeys into Puerto Rico began in 1938 when 409 rhesus macaques from India were delivered to the 38.5 ha island of Cayo Santiago to study their free-ranging ecology (Rawlins and Kessler, 1986; Southwick, 1989). The La Parguera primate breeding colony was established in 1961 on two islets along the southwestern coast of Puerto Rico to produce rhesus macaques for research purposes (Kerber et al., 1979). In 1966, a population of 57 rhesus macaques was introduced on the island of Desecheo. The islets of Cueva and Guayacán in La Parguera were stocked with macaques from Cayo Santiago and India (González-Martinez, 1995). Beginning in 1971, patas monkeys from Nigeria were also released on Cueva, and in 1979 patas were added to the rhesus population on Guayacán islet (Loy, 1989). In 1974-1975 the Caribbean Primate Center 
supplemented the rhesus population, aiming for a population of 2000 (Phoebus et al., 1989).

Little time had elapsed following the introductions before there was evidence that both rhesus and patas monkeys were escaping from the release sites (González-Martinez, 1996a,b). When the La Parguera facilities were closed in 1982, approximately 54 patas were "unaccounted for" (González-Martinez, 1998). After 1979, when the rhesus monkeys were moved to another island in the United States, an U.S. Food and Drug Administration (FDA) report classified a total of 175 rhesus individuals as missing (GonzálezMartínez, 2006).

In the early 1990s (1990-1993), González-Martinez (1998) estimated the size of the patas population on the Puerto Rico mainland to be approximately 120 individuals, with their distribution thought to be within a $125 \mathrm{~km}^{2}$ area of southwestern Puerto Rico (González-Martinez, 1998). The population of the rhesus monkeys was estimated to be approximately 130 individuals (González-Martínez, 2006). At the time, González-Martinez (1995) believed that the primates were not significantly impacting the environment, that agricultural damage was exaggerated, and that neither species of monkey could be eradicated. Nevertheless, González-Martinez (1995, 1996a,b) also clearly stated the potential for significant environmental and agricultural problems if invasive monkey populations increased in density and range.

Today, invasive patas and rhesus monkey numbers are estimated to be much higher than in the early 1990s, with an approximate combined geographical range for the two species of $600 \mathrm{~km}^{2}$ (Puerto Rico Department of Agriculture, unpublished data). Jensen et al. (2004) estimated the rhesus monkey population to be around 500 individuals based on the assumptions of plentiful food resources and an annual population growth rate of $15 \%$. Similarly, the Puerto Rico Department of Natural and Environmental Resources (DNER) estimate for 2003 was between 400 and 600 rhesus in approximately 13 clans and about 450 patas in 19 clans (R. López-Ortiz, DNER, per comm., 2007). The most recent (2006) estimate is from 550 to 600 patas in 9-11 clans (Massanet and Chism, 2007).

As expected, conflicts with human interests have been increasing accordingly. Monkey damage to agricultural interests is a major facet of conflict. Here, we quantify the economic costs of the monkeys to commercial agriculture using a survey of commercial farmers in southwestern Puerto Rico. We also include a discussion of other, unquantified sources of economic impact from the monkeys.

\section{Damage survey methods}

A survey was conducted in November-December 2006 among commercial 217 farmers in southwestern Puerto Rico within the range of invasive rhesus macaques and patas monkeys. The survey was a $100 \%$ sample from the list of commercial farmers in that area that had sought any sort of financial assistance or incentives from the Puerto Rico Department of Agriculture (PRDA). The financial aid sought by the farmers typically included a range of purposes such as fertilizer purchases or salary support. The PRDA does not provide funds to compensate for monkey damage nor to implement monkey damage management practices, and there was no incentive for farmers to inaccurately report information. The survey included over $90 \%$ of the commercial farmers in the target area (PRDA, personal communication).

The initial survey question asked farmers whether they had seen monkeys on their property. Further interview questions were only asked of those farmers having seen monkeys on their property. The next question asked those farmers if they had crops damaged by monkeys during 2002-2006. Farmers without monkey damage were asked no further questions. However, farmers having crop damage were asked for detailed information as to the amount of their losses during those years. They were asked to provide the crops damaged by monkeys and the amount of each crop lost for each year. Farmers with monkeys were also asked their annual expenditures on protecting their crops from monkeys, henceforth referred to as damage control costs. A further question asked farmers if they had switched crops or land use because of monkey damage. If so, they were asked for specifics for each year on the types and size (area) of crops they would have planted had it not been for monkey damage, and the land uses to which they switched.

PRDA statistics were used to apply standardized values for harvest sizes and values of crops. The price for each crop, as compiled by PRDA statistics, was averaged over the years 20022006. The average values for each crop were applied to the annual loss amounts to arrive at a dollar figure for losses for each crop on each farm each year. Total dollar losses for each crop across farms were accumulated each year, as well as the values of all crops lost across all farms each year. For calculating values lost by switching land uses from susceptible crops, PRDA average harvest statistics were first applied for the area of land on which those crops would have been grown, and the value of those projected harvests were also calculated using the average values as above. PRDA statistics on crop prices were also examined to evaluate whether downward trends existed that could be contributing factors in decisions to change land uses. The total cost from invasive monkey impacts on crops was calculated as the total value of actual monkey damage, plus the total value for losses from switching from susceptible crops, plus total damage control expenditures, minus the total value of the land use substituted for those crops discontinued due to monkey damage. Thus, for each year from 2002 to 2006, information was obtained by crop for the value of actual monkey damage, the losses from discontinuation of growing a crop, the values of the substituted land uses, and expenditures on damage prevention measures.

We considered a variety of other sources of economic impact from invasive monkeys, but neither data sources nor means to practically collect the data were available. These other impacts, in need of analyses and discussed later, include damage to small plot farmers and gardeners, damage to natural resources (especially endangered species), property damage, and disease transmission to humans, domestic animals and wildlife.

\section{Results}

Monkeys were widely dispersed across the commercial farms in southwest Puerto Rico, as 135 of the 217 (62\%) commercial farmers reported they had seen monkeys on their property. When they were shown photographs of the two species, $99 \%$ identified the patas monkeys. Only 21 of those farmers (16\%) having seen monkeys on their property also observed crop damage. However, monkey damage was often severe for those farmers who reported crop damage. Over half of the farmers $(57 \%, 12$ of 21$)$ reporting monkey damage made either a total or partial switch from crops damaged by monkeys to alternative crops or different land uses. Farmers primarily switched to pastureland or hay harvest from fruit and vegetable crops as a result of monkey damage, with most farmers having made their switches prior to 2004. Nine of the 12 farmers (75\%) that changed growing practices due to monkey damage completely quit growing those crops and switched to pastureland or growing hay. Five of the 21 (24\%) farmers with monkey damage reported expenditures for damage control and those expenditures were miniscule compared to crop losses (Table 4). 
By far, the greatest losses due to monkeys were to pumpkin crops, followed by watermelon, corn, cucumber, banana, papaya, and plantain (Table 1). Similarly, losses due to switching land use were led by pumpkins, followed by corn, watermelon, and papaya (Table 2). Considering prices increased from 2002 to 2006 for all crops damaged by monkeys, and the alternate land uses were typically of much less value than the crop they were substituting, it is unlikely that farmers felt compelled to switch from the susceptible crops due to market forces.

The actual amount of crops lost directly to monkeys declined annually from over $\$ 600 \mathrm{~K}$ in 2002 to about $\$ 300 \mathrm{~K}$ by 2005 and 2006 (Table 1). Most of this decrease in actual damage losses can be attributed to changes in agricultural practices to avoid crops susceptible to monkey damage. Consequently, the amount of losses based on changing land use to avoid monkey damage increased dramatically from almost a half million dollars in 2002 to over $\$ 1.3$ million by 2004 , a level at which it has remained since (Table 2 ). Overall, losses due to monkey damage, directly or from the threat of monkey damage, increased from over \$1.1 million in 2002 to over $\$ 1.45$ million in 2003. Losses remained in this neighborhood through 2006 (Table 4). The value of substitute land use grew rapidly as farmers made the switch from susceptible crops to land uses with lesser returns. The values obtained from the substitute land uses only made up for a fraction of the losses due to avoiding monkey damage by changing land uses (Tables 3 and 4). The value of crops that farmers gave up in favor of alternative land uses increased from 2002 to 2006 (Table 5), indicating that the land use switches were due to monkey losses rather than market forces. That there are few practical and legal means to effectively protect crops from monkeys is reflected in the relatively small expenditures on damage control methods (Table 4). Hence, the net losses due to monkeys were only slightly less than the total loss figures.

\section{Discussion}

\subsection{Values of crops lost to monkeys}

Total economic losses to commercial farmers from invasive monkeys were estimated from \$1.13 million USD to \$1.46 million per year from 2002 to 2006. These figures are undoubtedly conservative for total monkey damage to human interests, but also for agricultural losses, given the specific focus of the study. We have only considered the economic costs from invasive monkeys to the commercial farmers of Puerto Rico. Small plot farmers and gardeners were not included in the survey. Another consideration making the identified losses conservative is that multiple harvests per year are possible in Puerto Rico for pumpkin, watermelon, corn, and cucumber, but we only treated losses due to switching crops as single harvest crops. Therefore, if even a fraction of the farmers avoiding susceptible crops would have been considered to have had multiple harvests had they not changed land uses, then the value of the losses would have increased substantially. Thus, crop losses to monkeys identified by this study represent a minimum level for
Table 2

The value of crops discontinued by commercial farmers in southwestern Puerto Rico from 2002 to 2006 by switching from fruit and vegetable crops to pastureland and hay to avoid monkey damage.

\begin{tabular}{ccccrr}
\hline Year & \multicolumn{3}{l}{$\begin{array}{l}\text { Monkey losses due to switching crops excluding prior to switches } \\
(\$ 1000)\end{array}$} & \multicolumn{1}{c}{ Corn } & \multicolumn{1}{c}{ Total } \\
\cline { 2 - 6 } & Pumpkin & Watermelon & Papaya & \multicolumn{1}{c}{ Corn } \\
\hline 2002 & 403.2 & 53.8 & 13.8 & 21.2 & $\mathbf{4 9 2 . 0}$ \\
2003 & 676.8 & 207.4 & 13.8 & 286.2 & $\mathbf{1 1 8 4 . 2}$ \\
2004 & 820.8 & 207.4 & 13.8 & 286.2 & $\mathbf{1 3 2 8 . 2}$ \\
2005 & 820.8 & 207.4 & 13.8 & 286.2 & $\mathbf{1 3 2 8 . 2}$ \\
2006 & 820.8 & 207.4 & 13.8 & 286.2 & $\mathbf{1 3 2 8 . 2}$ \\
Total & $\mathbf{3 5 4 2 . 4}$ & $\mathbf{8 8 3 . 4}$ & $\mathbf{6 9 . 0}$ & $\mathbf{1 1 6 6 . 0}$ & $\mathbf{5 6 6 0 . 8}$ \\
\hline
\end{tabular}

economic impacts to agriculture in Puerto Rico. Even given their conservative nature, the identified losses are substantive and likely to grow as monkey populations increase in number and range.

It was not surprising to us that the majority of the losses were inflicted by patas monkeys. This species prefers open savannas habitats, which predominate in southwestern Puerto Rico, and from which croplands were primarily derived and adjoin. However, we speculate that as both species expand their ranges towards the forested hills and mountains to the north, the patas monkeys may be deterred by the increasingly heavily forested habitats, but the rhesus monkeys would thrive. We expect that if monkey range expansions are permitted to reach these areas, the rhesus macaques will dominate the agricultural damage there through depredations in fruit crops. Moreover, should information become available for the other forms of current damage discussed in following subsections, the rhesus macaques likely would predominate the damage to native wildlife, property, and through disease transmission.

\subsection{Other economic impacts from invasive monkeys}

\subsubsection{Impacts to natural resources}

Monkeys also harm native species in Puerto Rico, including species listed as threatened or endangered (USDA et al., 2008). Introduced rhesus monkey populations on Desecheo appear to have significantly impacted nesting colonies of red-footed booby (Sula sula), brown booby (Sula leucogaster), noddy tern (Anous stolidus), and bridled tern (Sternus anaethetus) (Evans, 1989; Raffaele, 1989). There also is evidence that monkeys are depredating nests of the endangered yellow-shouldered blackbirds (Agelaius xanthomus) on the Puerto Rico mainland (R. López-Ortiz, DNER, pers. comm.). DNER biologists believe that in less than a week in June 2002, monkeys destroyed the contents of 30 yellowshouldered blackbird nests (built in artificial nest structures) monitored by researchers in the Boquerón State Forest (R. LópezOrtiz, DNER, pers. comm.). Should monkeys expand their range to the forests of northeastern Puerto Rico, they might have severe effects on the wild population of Puerto Rican parrots, one of the ten most endangered birds in the world (U.S. Fish and Wildlife

Table 1

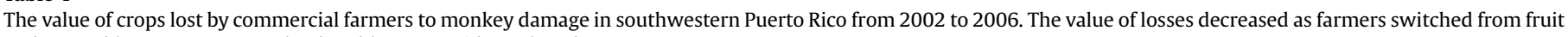
and vegetable crops to pastureland and hay to avoid monkey damage.

\begin{tabular}{|c|c|c|c|c|c|c|c|c|}
\hline \multirow[t]{2}{*}{ Year } & \multicolumn{8}{|c|}{ Actual monkey damage $(\$ 1000)$} \\
\hline & Pumpkin & Watermelon & Cucumber & Papaya & Plantain & Banana & Corn & Total \\
\hline 2002 & 217.3 & 78.0 & 18.9 & 8.3 & 3.2 & 37.2 & 132.5 & 603.3 \\
\hline 2003 & 249.7 & 74.1 & 18.9 & 6.9 & 3.2 & 26.6 & 0 & 379.4 \\
\hline 2004 & 206.8 & 74.3 & 18.9 & 6.9 & 3.2 & 16.0 & & 326.0 \\
\hline 2005 & 207.1 & 74.4 & 18.9 & 3.5 & 3.2 & & & 307.0 \\
\hline 2006 & 199.9 & 74.4 & 18.9 & 3.5 & 3.2 & & & 299.9 \\
\hline Total & 1188.7 & 375.2 & 94.5 & 29.0 & 16.0 & 79.8 & 132.5 & 1915.7 \\
\hline
\end{tabular}


Table 3

The value of substitute land uses substituted for crops discontinued by commercial farmers in southwestern Puerto Rico from 2002 to 2006 to avoid monkey damage.

\begin{tabular}{|c|c|c|c|c|c|c|c|c|}
\hline \multirow[t]{2}{*}{ Year } & \multicolumn{8}{|c|}{ Value of substitute land use ( $\$ 1000)$} \\
\hline & Papaya & Watermelon & Hay & Banana & Pasture & Sheep & Plantain & Total \\
\hline 2002 & & & 3.9 & & & 0.6 & & 4.5 \\
\hline 2003 & 110.6 & & 14.9 & & 7.5 & 1.5 & & 134.5 \\
\hline 2004 & 160.3 & 3.8 & 31.4 & & 7.5 & 1.5 & 49.7 & 254.2 \\
\hline 2005 & 49.7 & 3.8 & 34.1 & 51.2 & 7.5 & 1.5 & 49.7 & 197.5 \\
\hline 2006 & 49.7 & 3.8 & 34.1 & 51.2 & 7.5 & 1.5 & 49.7 & 197.5 \\
\hline Total & 370.3 & 11.4 & 118.4 & 102.4 & 30.0 & 6.6 & 149.1 & 788.2 \\
\hline
\end{tabular}

Service, 1999; Engeman et al., 2006). Were specific data available to quantify losses of threatened and endangered wildlife to monkeys, those losses could be monetarily valued by various means (e.g., Engeman et al., 2004), and the resulting information could be used in economic analyses to characterize the benefit-costs of monkey damage management for endangered species conservation.

\subsubsection{Property damage}

Currently, damage to property from invasive monkeys in Puerto Rico is not well documented and is likely limited to isolated incidents where monkeys cause damage while searching for food, or through such means as automobile accidents incurred while avoiding a collision with a monkey. Monkeys in Puerto Rico have not yet formed a commensal relationship with humans such as commonly found with rhesus monkeys in their native India. However, as the monkey populations in Puerto Rico continue to increase, they may form a more commensal relationship with humans. As populations expand near residential areas, there is potential for people to begin feeding monkeys, thereby conditioning them to associate people with the feeding (USDA et al., 2008). This association can lead to attacks on people and damage to property as monkeys search for food in residential areas.

\subsubsection{Disease transmission}

Another significant concern, with accompanying economic ramifications, is the increasing potential for disease transmission from monkeys to humans in Puerto Rico. In particular, herpes B-virus (Cercopithecine herpesvirus) is highly prevalent among free-ranging rhesus macaques in Puerto Rico. B-virus is a alphaherpesvirus enzootic in the genus Macaca, which includes the rhesus monkey. B-virus exhibits mild effects in macaque hosts but is $70 \%$ fatal when contracted by humans, with survivors often having moderate to severe neurologic impairment (Palmer, 1987; Huff and Barry, 2003; Jensen et al., 2004). In 1967, 82\% of rhesus monkeys sampled in Cayo Santiago were seropositive for the B-virus (Kessler and Hilliard, 1990), a finding consistent with the general data that indicate a high rate of B-virus infection in adult rhesus monkeys ranging from $74 \%$ to $100 \%$ (Orcutt et al., 1976; Weigler, 1992). Cohen et al. (2002) recommend all macaques be treated as potentially infectious.

\section{Table 4}

The net values of losses by commercial farmers in southwestern Puerto Rico from 2002 to 2006 due to monkeys. The columns indicate losses due to actual damage, losses due to switching from fruit and vegetable crops to pastureland or hay, the costs of damage control measures, and the gains from the substitute land uses.

\begin{tabular}{lcrlll}
\hline \multirow{2}{*}{ Year } & \multicolumn{6}{l}{ Total net monkey losses $(\$ 1000)$} \\
\cline { 2 - 6 } & Damage & Switch & Control costs & (Value substitute use) & Total \\
\hline 2002 & 603.3 & 492.0 & 39.9 & $(4.4)$ & $\mathbf{1 1 3 0 . 8}$ \\
2003 & 379.4 & 1184.2 & 39.9 & $(134.4)$ & $\mathbf{1 4 6 9 . 1}$ \\
2004 & 326.0 & 1328.2 & 39.9 & $(254.2)$ & $\mathbf{1 4 3 9 . 9}$ \\
2005 & 307.0 & 1328.2 & 29.6 & $(197.5)$ & $\mathbf{1 4 6 7 . 3}$ \\
2006 & 299.9 & 1328.2 & 29.6 & $(197.5)$ & $\mathbf{1 4 6 0 . 2}$ \\
Total & $\mathbf{1 9 1 5 . 6}$ & $\mathbf{5 6 6 0 . 8}$ & $\mathbf{1 7 8 . 9}$ & $\mathbf{( 7 8 8 . 0 )}$ & $\mathbf{6 9 6 7 . 3}$ \\
\hline
\end{tabular}

Human exposures will likely increase as the expanding monkey populations in Puerto Rico result in increasing numbers of people encountering monkeys with a corresponding increase in the possibility of disease transmission. Increasing crop damage has led to an increasing chance of disease exposure through damage management efforts (USDA et al., 2008). There are also reports of increased illegal trapping of monkeys for sale as exotic pets, which could also increase the possibility of exposure (Jensen et al., 2004). Ostrowski et al. (1998) state that contact between humans and free-ranging macaques cannot be safely controlled. Underscoring the seriousness of the potential problem, a mass exposure to a B-virus positive rhesus monkey has already taken place in Puerto Rico. During an accident involving an automobile and an adult male rhesus monkey, 25 emergency personnel were exposed to blood and other bodily fluids of the monkey, which later tested positive for B-virus antibodies (Cercopithecine herpesvirus) (Jensen et al., 2004). No emergency personnel contracted B-virus, but all personnel indicated they were unaware of the disease risks associated with monkeys in Puerto Rico (Jensen et al., 2004). Even if disease transmission does not occur, there can be significant medical costs associated with the exposure (e.g., Shwiff et al., 2007)

In addition to B-virus, monkeys have been known to transmit numerous other diseases to humans (Wolfe et al., 1998). Rabies is ubiquitous in Puerto Rico (Blanton et al., 2007) and could be a serious health risk if monkeys begin invading urban areas. The Indian mongoose (Herpestus auropunctatus) is the primary source of rabies in Puerto Rico. Interactions between monkeys and mongooses in Puerto Rico could lead to exposure of monkeys to the virus. This probably would not occur to the extent that rabies therefore would be a controlling factor for overall monkey populations. However, monkeys are a source for exposure and transmission of rabies to humans in many places around the world (e.g., Wilde et al., 1990; Pandey et al., 2002; Tefera et al., 2002; Chhabra et al., 2004; Pfukenyi et al., 2009). Rabies could become prevalent in an exposed group or clan of monkeys, which in turn could lead to human or domestic animal exposure through contact with monkeys, especially if monkey populations continue to increase and become commensal with humans (USDA et al., 2008).

Human exposure to wildlife transmitted diseases especially potentially fatal diseases, has been shown to hold costly medical expenses. For example, Shwiff et al. (2007) found there were direct

Table 5

The prices for fruit and vegetable crops grown by commercial farmers in southwestern Puerto Rico from 2002 to 2006

\begin{tabular}{lllllll}
\hline \multirow{2}{*}{ Year } & \multicolumn{5}{l}{ Crop price $\left(^{*}=\right.$ per quintal, ${ }^{* *}=$ per thousand $)$} \\
\cline { 2 - 7 } & Pumpkin* $^{*}$ Papaya* $^{*}$ & Watermelon* & Corn $^{* *}$ & Cucumber $^{*}$ & Plantain** \\
\hline 2002 & 18.8 & 19.8 & 16.5 & 211.6 & 21.1 & 122.7 \\
2003 & 20.6 & 23.3 & 15.7 & 241.3 & 19.9 & 140.5 \\
2004 & 21.6 & 22.1 & 14.2 & 269.9 & 19.9 & 147.2 \\
2005 & 30.1 & 23.8 & 14.3 & 298.5 & 22.1 & 166.3 \\
2006 & 29.8 & 26.2 & 17.6 & 302.3 & 23.1 & 183.4 \\
Mean & $\mathbf{2 4 . 2}$ & $\mathbf{2 3 . 0}$ & $\mathbf{1 5 . 6}$ & $\mathbf{2 6 4 . 7}$ & $\mathbf{2 1 . 2}$ & $\mathbf{1 5 2 . 0}$ \\
\hline
\end{tabular}


and indirect costs associated with human exposure to rabies. Direct costs included immediate wound treatment (e.g. emergency room visits) and post-exposure prophylaxis (PEP). Indirect costs included over-the-counter medicines, travel costs to and from medical treatments, day care and others. The indirect costs associated with this wildlife transmitted disease were found to comprise approximately $1 / 3$ of the total cost. Expenditures to prevent or reduce transmission of zoonotic diseases from wildlife to humans can prevent additional costs while offering future savings in excess of prevention measures. For example, oral rabies vaccination (ORV) programs designed to prevent the spread of rabies in wildlife can be costly, but the savings associated with reduced PEP treatments and animal testing usually justify expenditures (Shwiff et al., 2008). Efforts to prevent the spread of monkeys to protect agriculture would also serve to reduce the threat and associated costs from disease transmission.

\section{Conclusions}

Crop losses to commercial farmers in Puerto Rico due to monkeys (particularly patas monkeys) are substantial and likely to increase without significant intervention to manage monkey populations. Wide-scale coordinated efforts to manage monkey populations have not been in effect, although capture and removal of monkeys take place in localized circumstances. The losses reported here define a lower bound for the negative economic impacts from invasive monkeys in Puerto Rico. As other impacts are further identified and measured, the economic costs from these monkeys in Puerto Rico could be severe. Elimination of an incipient population of an invasive species is accomplished far more easily and cost-effectively than a population that has been allowed to grow and spread. Invasive monkeys in Puerto Rico could have been eliminated fairly efficiently in the early 1990s when their populations occupied around $125 \mathrm{~km}^{2}$. Now a far greater effort will be needed to hold the line in their advances in number and range, let alone reduce their populations, or even eradicate them. If the problem is allowed to persist, the difficulties in management will be magnified many fold and losses could well be incalculable.

\section{References}

Blanton, J.D., Hanlon, C.A., Rupprecht, C.E., 2007. Rabies surveillance in the United States in 2006. Journal of the American Veterinary Medical Association 231, 540-556.

Chhabra, M., Ichhpujani, R.L., Tewari, K.N., Lal, S., 2004. Human rabies in Delhi. Indian Journal of Pediatrics 71, 217-220.

Cohen, J.I., Davenport, D.S., Stewart, J.A., Deitchman, S., Hilliard, J.K., Chapman, L.E., 2002. The B Virus Working Group. Recommendations for prevention of and exposure to B virus (Cercopithicine herpesvirus 1). Clinical Infectious Diseases 35, 1191-1203.

Engeman, R., Shwiff, S., Smith, H., Constantin, B., 2004. Monetary valuation of rare species and imperiled habitats as a basis for economically evaluation conservation approaches. Endangered Species Update 21, 66-73.

Engeman, R.M., Whisson, D.A., Quinn, J., Cano, F., White Jr., T., 2006. Monitoring invasive mammalian predator populations sharing habitat with the critically endangered Puerto Rican parrot Amazona vittata. Oryx 40, 95-102.

Evans, M.A., 1989. Ecology and removal of introduced rhesus monkeys: Desecheo Island National Wildlife Refuge, Puerto Rico. Puerto Rico Health Sciences Journal 8, 139-156.

González-Martinez, J., 1995. Ecology of the introduced free-ranging patas and rhesus monkeys of Southwestern Puerto Rico. Ph.D. thesis, University of Colorado, Boulder, Co., 158 pp.

González-Martinez, J., 1996a. Ecology of the introduced free-ranging patas and rhesus monkeys of southwestern Puerto Rico. Dissertation Abstracts International B57 (1), 68.

González-Martinez, J., 1996b. Development of a Program to Mitigate Crop Damage by Monkeys and to Contain and Monitor their Populations, Proposal submitted to the UPR/MSC, PRDA, and PR DNER. Caribbean Primate Research Center, Sabana Seca, Puerto Rico, 13 pp.

González-Martinez, J., 1998. The ecology of introduced patas monkey (Erythrocebus patas) population of southwestern Puerto Rico. American Journal of Primatology 45, 351-365.

González-Martínez, J., 2006. Plan para el manejo, control, y eventual erradicación de las poblaciones de monos rhesus y patas que habitan en el suroeste de Puerto Rico. Proposal submitted to the Puerto Rico Department of Agriculture. Caribbean Primate Research Center, Sabana Seca, Puerto Rico.

Huff, J.L., Barry, P.A., 2003. B-virus (Cercopithecine herpesvirus 1) infection in humans and macaques: potential for zoonotic disease. Emerging Infectious Diseases 9 (2), 246-250.

Jensen, K., Alvarado-Remy, F., González-Martinez, J., Kraiselburd, E., Rulluan, J., 2004. B-virus and free-ranging macaques, Puerto Rico. Emerging Infectious Diseases 10 (3), 494-496.

Kerber, W.T., Herbert, H.J., Vickers, J.H., 1979. Establishing a free-ranging breeding colony of rhesus monkeys. Part I. Journal of Medical Primatology 8, 129-142.

Kessler, M.J., Hilliard, K., 1990. Seroprevalence of B virus (Herpesvirus simiae) antibodies in a naturally formed group of rhesus macaques. Journal of Medical Primatology 19, 155-160.

Loy, J., 1989. Studies of free-ranging and corralled patas monkeys at La Parguera, Puerto Rico. Puerto Rico Health Sciences Journal 8, 129-131.

Massanet, M., Chism, J., 16-18 March 2007. Monkeys on a Caribbean island: an introduced patas monkey population in Puerto Rico. In: Abstracts of the 4th Southeastern Ecology and Evolution Conference. University of Central Florida, p. 31.

Orcutt, R.P., Pucak, G.J., Foster, H.L., Kilcourse, J.T., Ferrell, T., 1976. Multiple testing for the detection of B-virus antibody in specially handled rhesus monkeys after capture from virgin trapping grounds. Laboratory Animal Science 26, 70-74.

Ostrowski, S.R., Leslie, M.J., Parrott, T., Abelt, S., Piercy, P.E., 1998. B-virus from pet macaque monkeys: an emerging threat in the United States? Emerging Infectious Diseases 4 (1), 117-121.

Palmer, A.E., 1987. B virus, Herpesvirus simiae: historical perspective. Journal of Medical Primatology 16, 99-130.

Pandey, P., Shlim, D.R., Cave, W., Springer, M.F.B., 2002. Risk of possible exposure to rabies among tourists and foreign residents in Nepal. Journal of Travel Medicine 9, 127-131.

Pfukenyi, D.M., Pawandiwa, D., Makaya, P.V., Ushewokunze-Obatolu, U., 2009. A retrospective study of wildlife rabies in Zimbabwe, between 1992 and 2003. Tropical Animal Health and Production 41, 565-572.

Phoebus, E.C., Romain, A., Herbert, H.J., 1989. The FDA rhesus breeding colony at La Parguera. Puerto Rico Health Sciences Journal 8, 157-158.

Raffaele, H.A., 1989. A guide to birds of Puerto Rico and the Virgin Islands. Princeton University Press, Princeton, NJ, 254 pp.

Rawlins, R.G., Kessler, M.J., 1986. The Cayo Santiago Macaques - History, Behavior and Biology. State University of New York Press, Albany, NY, 306 pp.

Sekhar, N.U., 1998. Crop and livestock depredation caused by wild animals in protected areas: the case of Sariska Tiger Reserve, Rajasthan, India. Environmental Conservation 25, 160-171.

Shwiff, S.A., Sterner, R.T., Jay-Russell, M., Parikh, S., Bellomy, A., Meltzer, M.I., Rupprecht, C.E., Slate, D., 2007. Estimating the direct and indirect cost of rabies exposure: a retrospective study in Southern California. Journal of Wildlife Diseases 43, 251-257.

Shwiff, S.A., Kirkpatrick, K.N., Sterner, R.T., 2008. Economic evaluation of an oral rabies vaccination program for control of a domestic dog-coyote rabies epizootic: 1995-2006. Journal of the American Veterinary Medical Association 233, 1736-1741.

Southwick, C.H., 1989. The role of Cayo Santiago in primate field studies. Puerto Rico Health Sciences Journal 8, 47-51.

Tefera, G., Yimer, E., Geyid, A., 2002. Endemic existence of rabies in Ethiopia. Ethiopian Medical Journal 40, 163-170.

(USDA, DNER, PRDA, USFWS) US. Department of Agriculture/Animal and Plant Health Inspection Service/Wildlife Services, Puerto Rico Department of Environmental and Natural Resources, Puerto Rico Department of Agriculture, U.S. Fish and Wildlife Service, 2008. Environmental Assessment: Management of Feral and Free-ranging Patas and Rhesus Monkey Populations to Reduce Threats to Human Health and Safety, Agriculture, Nuisances, and Impacts to Native Wildlife Species in the Commonwealth of Puerto Rico. USDA/Animal and Plant Health Inspection Service, Washington, D.C., 87 pp.

U.S. Fish and Wildlife Service, 1999. Technical/Agency Draft Revised Recovery Plan for the Puerto Rican Parrot (Amazona vittata). U.S.F.W.S. Region 4, Atlanta, GA, 77 pp.

Weigler, B.J., 1992. Biology of B-virus in macaque and human hosts: a review. Clinical Infectious Diseases 14, 555-567.

Weladji, R.B., Tchamba, M.N., 2003. Conflict between people and protected areas within the Benoue Wildlife Conservation Area, North Cameroon. Oryx 37, 72-79.

Wilde, H., Chutivongse, S., Tepsumethanon, W., Choomkasien, P., Polsuwan, C., Lumbertdacha, B., 1990. Rabies in Thailand: 1990. Review of Infectious Diseases 13, 644-652.

Wolfe, N.D., Escalante, A.A., Karesh, W.B., Kilbourne, A., Spielman, A., Lal, A.A., 1998. Wild primate populations in emerging infectious disease research: the missing link? Emerging Infectious Diseases 4 (2), 149-157. 